\title{
THE EVALUATION OF THE INTERNAL AUDIT RISK REGARDING PUBLIC PROCUREMENTS
}

\author{
Lect. Iulian Bogdan DOBRA, PhD Student \\ University of Alba lulia "1 Decembrie 1918"
}

From the six types of procedures that assign the public procurements' contracts, this paper wants to highlight the risk evaluation only for The public procurements carried out through demands of supply. The procurements carried out through electronic auctions were not treated within this paper.

Evaluating the risks is part of the operational process and must identify and examine the internal and external factors which could negatively impact the objectives of the organization ${ }^{1}$.

The risk analysis must cover the entire range of risks found within the entity, that is why it must be taken into account that the work procedures are kept at all levels of the hierarchy, especially at the top.

The evaluation process must discover the measurable and nonmeasurable risks, such as the operational risks, and must select the controllable risks.

Management can identify the risks and their evolution at the level of the entity with the help of a set of activities that organize, lead and manage and activities of pre-established control (through the specific department). The internal audit structure is an independent structure and resumes the analysis of the risks established by the management in order to evaluate the control system or the work procedures.

Internal auditors must report the results of their work to the general management and any significant weakness discovered during the audit mission. But, on the other hand, we must not forget that auditors also face a risk, such as the detection risk, called the audit risk. Therefore, the internal auditor must consider the audit risk at the level of

\footnotetext{
${ }^{1}$ GHIȚĂ M., - "Auditul Intern", Editura Economică, Bucharesti, 2004, pag. 118;
}

each operation as being an auditable object so that a low number of remained material errors are recorded.

Treating the risk must take into account their division into three large categories, according to the international audit standards:

a) Inherent risk - which emphasizes the situation when a material error can occur. The inherent risks are represented by the sum of risks that the entity faces and they can be internal, external, measurable or non-measurable. At this level, the control activity and its capacity to detect misstatements are ignored. The entity encounters these risks through its activity and intercessions.

b) The control risk - shows that the internal control system of the entity can't stop or correct possible errors. The control risks represent the undiscovered irregularities and errors during the control activity. The analysis of the control risks is done in accordance with the organization' structure of the control system, the organization and application of the procedures, of the used IT system, etc. The auditor can't change the control's level and quality, but he can "influence it by making recommendations regarding the improvement, but this influence can manifest only after the audit and only if the management will take into account the made suggestions" ${ }^{2}$.

c) The detection risk - represents the situation when a material misstatement will not be detected by the auditors, and is also called the audit risk.

\footnotetext{
2 GENETE L.,D., -"Evaluarea riscului în auditul financiar contabil. Metode cantitative şi metode calitative", ANALELE ŞTIINȚIFICE ALE UNIVERSITĂȚII „ALEXANDRU IOAN CUZA” DIN IAŞI,Tomul LII/LIII Ştiințe Economice 2005/2006, p. 60.
} 
Unlike the inherent risk and the control risk, the detection risk can be "supervised" by the auditor through:

$>$ the adequate planning of the audit mission;

$>$ the conformable establishing of the audit works' nature, duration and spreading;

$>$ efficient audit procedures adapted, evaluated, etc.

The objectives, just as they are stipulated in the Methodological handbook of internal audit regarding the public procurement of supply, works and services (referred to as Handbook) assure us that:

$>$ the generally accepted principles within the European Union were taken into account when making a decision:

o the free competition principle implies ensuring conditions for every supplier of products, services or work executor, no matter the nationality, to have the right to become a contractor, within the conditions of the law;

o the principle of the efficient use of public funds implies applying the economic criteria to award the public procurement contract within the competition system.

o the transparency principle implies putting at the disposal of those who are interested all the information regarding the procedures followed to award a public procurement contract;

o the equal treatment principle implies applying in a non-discriminatory manner the selection criteria for awarding a public procurement contract;

o the confidentiality principle implies guaranteeing the commercial secret and the right to intellectual property of the tenderer.

$>$ the acquisition activity is well known and mastered from the beginning and launching phases to the final reimbursements;

$>$ the Annual program of public procurements is adequate to the real, valid, foreseen in the budget and scheduled needs;

$>$ the recordings are exhaustive;

$>$ the documents are accurately certified and recorded;

$>$ the expenses correspond to a provided service;

$>$ the functionality of the internal control system.

Next, we want to emphasize the risk measurement with the help of the risk assessment matrix. It is known that the risk assessment (analysis) activity represents an essential component of management and must be done constantly. It includes the following stages: identifying the auditable objects, establishing the risk for each auditable object, assessing the risks, classifying the risks, establishing the internal control and placing the risks on a hierarchy.

At the level of the risk assessment stage we will try to highlight the assessment criteria and the weights of the risk regarding: the financial impact, the occurrence probability and the level of the internal control (the implementation degree of the specific control procedures).

According to the Handbook, the audit mission for the public procurement activity has a List of auditable objects for the demands of supply that includes the following:

Table no. 1 List of auditable objects for the public procurement activity

\begin{tabular}{|c|c|c|c|}
\hline Nr. & Objectives (O.) & Auditable objects (Ob.) & Observations \\
\hline 1. & $\begin{array}{l}\text { Preparing the procedure } \\
\text { for awarding public } \\
\text { procurements contracts } \\
(0.1)\end{array}$ & $\begin{array}{l}\text { The market study, creating its own data base } \\
\quad \text { Writing and transmitting the Documentation } \\
\text { necessary for the elaboration and presentation of } \\
\text { the supply (DEPO); } \\
\quad \text { Establishing the evaluation commissions. }\end{array}$ & \\
\hline 2. & $\begin{array}{l}\text { Launching the } \\
\text { procedure for awarding } \\
\text { public procurements } \\
\text { contracts }(\mathrm{O} .2)\end{array}$ & $\begin{array}{l}\text { The announcement/invitation to participate } \\
\text { The right to demand clarifications at DEPO }\end{array}$ & \\
\hline 3. & The unfolding of the & Opening and assorting the tenders; & \\
\hline
\end{tabular}




\begin{tabular}{|c|c|}
\hline $\begin{array}{l}\text { procedure for awarding } \\
\text { public procurements } \\
\text { contracts }(0.3)\end{array}$ & $\begin{array}{l}\text { Examining and evaluating the tenders in order } \\
\text { to establish the winner of the public procurement } \\
\text { contract; } \\
\quad \text { Signing the public procurement contract; } \\
\quad \text { The public procurement file. }\end{array}$ \\
\hline
\end{tabular}

Source: An internal audit mission handbook for the public procurement activity, elaborated by U.C.A.A.P.I.

In the second stage of the risk analysis procedure, called Risk identification, the association of the significant risks with the operations established in the List of auditable objects takes place. Usually, the internal auditors associate one or more theoretical risks to auditable objects, based on what was determined from the collected documents or from the practical risks emerged from its own experience. The handbook stipulates the following categories of risks specific to every auditable object:

Table no. 2 Identifying the risks of the auditable objects for the public procurement activity

\begin{tabular}{|c|c|c|c|}
\hline $\begin{array}{l}\text { Nr. } \\
\text { Crt. }\end{array}$ & Auditable objects & Significant risks (Rs.) & Observations \\
\hline 0.1. & $\begin{array}{l}\text { The market study, } \\
\text { creating its own data } \\
\text { base (Ob.1.1); } \\
\text { Writing and } \\
\text { transmitting the } \\
\text { Documentation } \\
\text { necessary for the } \\
\text { elaboration and } \\
\text { presentation of the } \\
\text { supply (DEPO) } \\
\text { (Ob.1.2); } \\
\text { Establishing the } \\
\text { evaluation } \\
\text { commissions.(Ob.1.3) }\end{array}$ & $\begin{array}{l}\text { An insufficient information system, which doesn't } \\
\text { allow going over the representative tenders (Rs.1.1.1); } \\
\quad \text { DEPO doesn't observe the conformity conditions } \\
\text { (Rs.1.2.1); } \\
\text { a certain economic agent (Rs.1.2.2); } \\
\$ \quad \text { The decision to name an evaluation commission } \\
\text { doesn't meet the conformity conditions (Rs.1.3.1); } \\
\text { have members of the evaluation commission don's } \\
\text { area (Rs.1.3.2); } \\
\text { There is an incompatibility between the members of } \\
\text { the evaluation commission and the tenderers (not all the } \\
\text { confidentiality and impartiality statements are signed) } \\
\text { (Rs.1.3.3); } \\
\quad \text { Establishing a single evaluation commission to } \\
\text { award more contracts of public procurement (Rs.1.3.4). }\end{array}$ & \\
\hline 0.2 & $\begin{array}{l}\text { The } \\
\text { announcement/ } \\
\text { invitation to } \\
\text { participate (Ob.2.1) } \\
\text { The right to } \\
\text { demand } \\
\text { clarifications at } \\
\text { DEPO (Ob.2.2). }\end{array}$ & $\begin{array}{l}\quad \text { The announcement/invitation to participate doesn't } \\
\text { observe the conformity conditions (Rs.2.1.1); } \\
\text { The invitation to participate is sent by chance, without a } \\
\text { previous selection of the market (Rs.2.1.2); } \\
\text { Sending a single invitation (Rs.2.1.3); } \\
\text { The answer deadlines at the clarifications' demands are } \\
\text { not hold (Rs.2.2.1); } \\
\text { The clarifications and additions written by DEPO are not } \\
\text { transmitted to all the tenderers who received the initial } \\
\text { documentation (Rs.2.2.2). }\end{array}$ & \\
\hline 0.3. & $\begin{array}{l}\text { Examining and } \\
\text { evaluating the } \\
\text { tenders in order to } \\
\text { establish the winner } \\
\text { of the public } \\
\text { procurement } \\
\text { contract (Ob.3.2); }\end{array}$ & $\begin{array}{l}\text { The minute of the tenders' opening doesn't observe the } \\
\text { conformity conditions (Rs.3.1.1); } \\
\text { The submitted tender doesn't meet the demands } \\
\text { stipulated by DEPO (Rs.3.1.2); } \\
\text { Accepting tenders which are not qualified (Rs.3.1.3); } \\
\text { The submitted tender is not accompanied by the proof of } \\
\text { a warrantee for participation, when necessary (Rs.3.1.4); } \\
\text { * The evaluation of the tenders is not done in accordance } \\
\text { with the terms stipulated in the specification (Rs.3.2.1); } \\
* \quad \begin{array}{l}\text { The erroneous establishing of the tenders' top } \\
\text { (Rs.3.2.2); }\end{array} \\
\text { * The evaluation report for the tender and the proposal to } \\
\text { award the contract don't comply with the conformity } \\
\text { conditions (Rs.3.2.3) } \\
* \quad \begin{array}{l}\text { The evaluation's result is not communicated to the } \\
\text { participants (Rs.3.2.4) }\end{array} \\
\text { Closing the acquisition contract doesn't comply with the } \\
\text { conformity conditions (Rs.3.3.1) }\end{array}$ & \\
\hline
\end{tabular}




\begin{tabular}{|c|c|c|}
\hline $\begin{array}{l}\text { * Signing the public } \\
\text { procurement } \\
\text { contract (Ob.3.3); } \\
\text { - The public } \\
\text { procurement file } \\
\text { (Ob.3.4). }\end{array}$ & $\begin{array}{l}* \\
* \\
* \\
*\end{array}$ & $\begin{array}{l}\text { The contract is not signed with the tenderer who won the } \\
\text { procedure (Rs.3.3.2); } \\
\text { The existence of differences between the terms } \\
\text { stipulated in the specification and the ones in the closed } \\
\text { procurement contract (Rs.3.3.3); } \\
\text { The performance bond is under the imposed level or is } \\
\text { not formed (Rs.3.3.4); } \\
\text { The public procurement file doesn't observe the } \\
\text { conformity conditions (Rs.3.4.1); } \\
\text { Destroying the public procurement file before the } \\
\text { minimum limit of the legal deadline (Rs.3.4.2); } \\
\text { Keeping the files in inadequate locations and/or } \\
\text { conditions (Rs.3.4.3) }\end{array}$ \\
\hline
\end{tabular}

Source: An internal audit mission handbook for the public procurement activity, elaborated by U.C.A.A.P.I.

The next stage of the risk analysis procedure is called Risk assessment, a stage where the weights and the level of the risk assessment are set, depending on the importance and the gravity of the risk factors.

In order to ease establishing the weight of the risk factors $(\mathrm{Pi})$, is more useful to mark in the third stage every auditable object with its corresponding specific risk with a certain simplified notation (for example: Ob. 1.1, Rs.1.1.1, Ob.i.1, Rs.i.1.1).

The handbook mentions the following risk factors, weights and assessment levels as follows:

a) the risk factors (Fi): F1 - the internal control assessment, F2 - the quantitative assessment, F3 - the qualitative assessment;

b) the weight of the risk factors $(\mathrm{Pi})$ : $\mathrm{P} 1$ - the weight of the internal control assessment (of the internal control procedures), which is $55 \%, \mathrm{P} 2$ - the weight of the quantitative assessment, which is at $25 \%, \mathrm{P} 3$ - the weight of the qualitative assessment, which is $20 \%$;

c) the risk assessment levels (Ni): N1 - low risk level, N2 - medium risk level, N3 - high risk level.

Therefore, the calculus relation of the total score for assessing the size of the risk is:

$$
P_{i=1}^{n}=\Sigma\left(P_{i} \times N_{i}\right)
$$

where:

$\mathrm{P}_{\mathrm{t}}$ - total score;

$\mathrm{P}_{\mathrm{i}}$ - the weight of the risk for each factor;
$\mathrm{N}_{\mathrm{i}}$ - the risk assessment level for each used factor

$i$ - the used risk factors factors

$n$ - the number of the used risk

In order to assess the risks for auditable objects, which are corresponding to the public procurement activity, we suggest the following criterion to settle the risk factors, the weights and the risk assessment level:

a) To assess the internal control $(\mathrm{F} 1)$, the number one objective (Ob. 1) and the third objective (Ob. 3) respectively, must have a $60 \%$ weight of the risk factors and the second objective (Ob. 2) must have a $55 \%$ weight. We think that higher weights for the two objectives (Ob.1\& Ob.3) are justified because of the importance of the auditable objects and of the risks associated to these objectives for the public procurement activity.

b) The qualitative assessment is done for all the objectives with a 35\% weight of the risk factors, which is associated with the quantitative assessment (F2). A higher weight of the risks than the one in the Handbook was established because of the meaning of the financial impact over the public procurement activity.

c) For the number one and number three objectives was considered a $5 \%$ weight of the risk factors, and a $10 \%$ weight for objective number two, which is associated to the qualitative assessment (F3).

The total score for each objective (Table no. 3), each auditable object and significant risk was determined with the formula: 


$$
\begin{aligned}
& P_{t} \stackrel{n}{=} \Sigma\left(P_{i} \times N_{i}\right)=> \\
& P_{\mathrm{t}} \text { 1.1.1 }=\mathrm{P}_{\mathrm{ci}} \text { 1.1.1 } \mathrm{xN}_{\mathrm{ci}} \text { 1.1.1 }+\mathrm{P}_{\mathrm{q}} \text { 1.1.1 } \mathrm{xN}_{\mathrm{q}} \text { 1.1.1 }+\mathrm{P}_{\mathrm{c}} \text { 1.1.1 } \mathrm{xN}_{\mathrm{c}} \text { 1.1.1 } \\
& P_{t} \text { 1.2.1 }=P_{c i} 1.2 .1 \times N_{c i} 1.2 .1+P_{q} 1.2 .1 \mathrm{xN}_{q} \text { 1.2.1 }+P_{c} 1.2 .1 \mathrm{xN}_{c} 1.2 .1 \\
& P_{t} \text { 3.4.3 }=P_{c i} 3.4 .3 x_{c i} 3.4 .3+P_{q} 3.4 .3 x_{q} 3.4 .3+P_{c} 3.4 .3 x_{c} 3.4 .3
\end{aligned}
$$

$\mathrm{P}_{\mathrm{ci}}$ - the weight of the risks for the internal control assessment;

$\mathrm{P}_{\mathrm{q}}$ - the weight of the risks for the quantitative assessment;

$\mathrm{P}_{\mathrm{c}}$ - the weight of the risks for the qualitative assessment; internal control;

$\mathrm{N}_{\mathrm{q}}$ - the risk assessment level for the quantitative assessment;

$\mathrm{N}_{\mathrm{c}}$ - the risk assessment level for the qualitative assessment;

Table no. 3 Assessing the auditable objects' risk for the public procurement activity

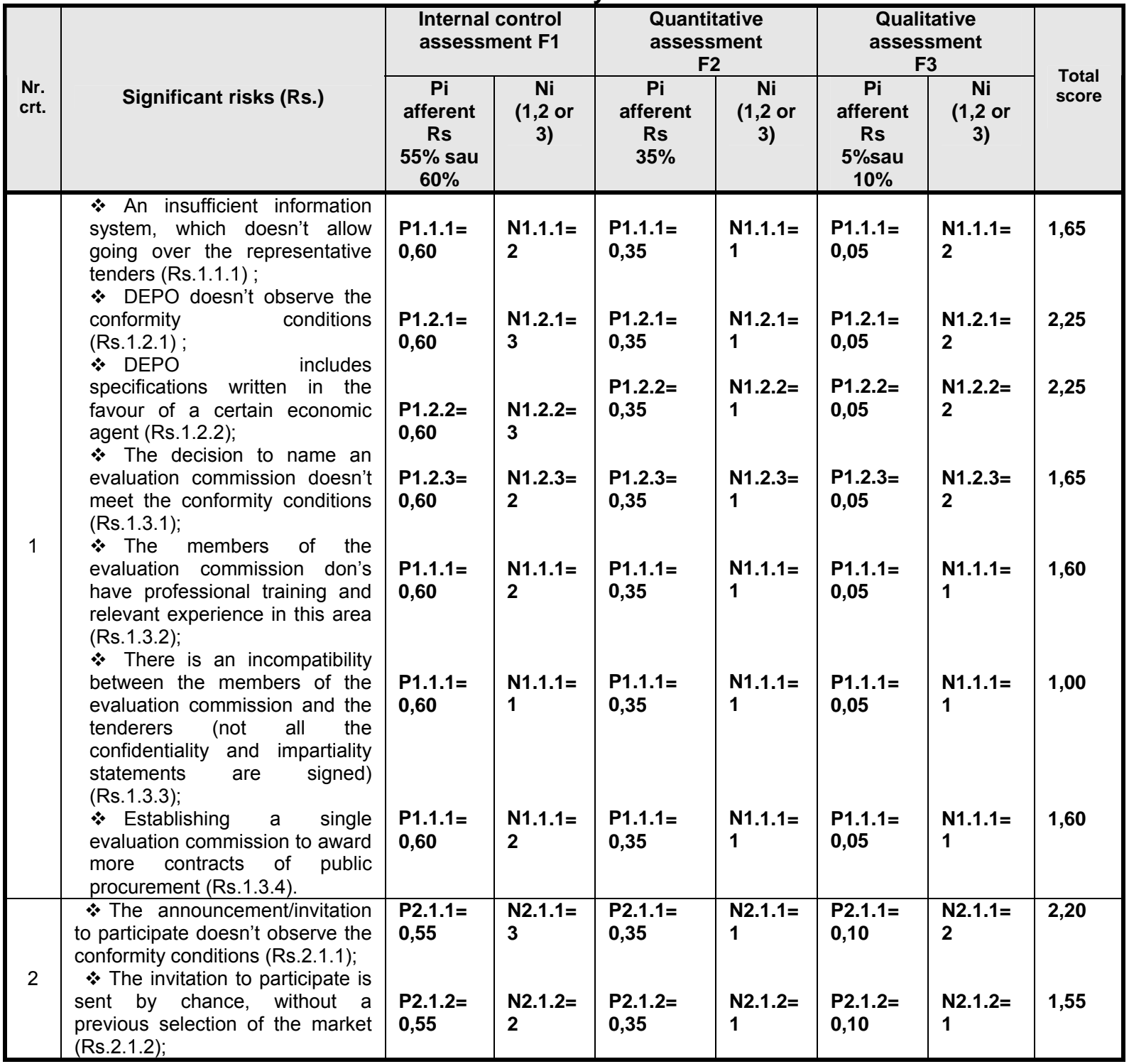




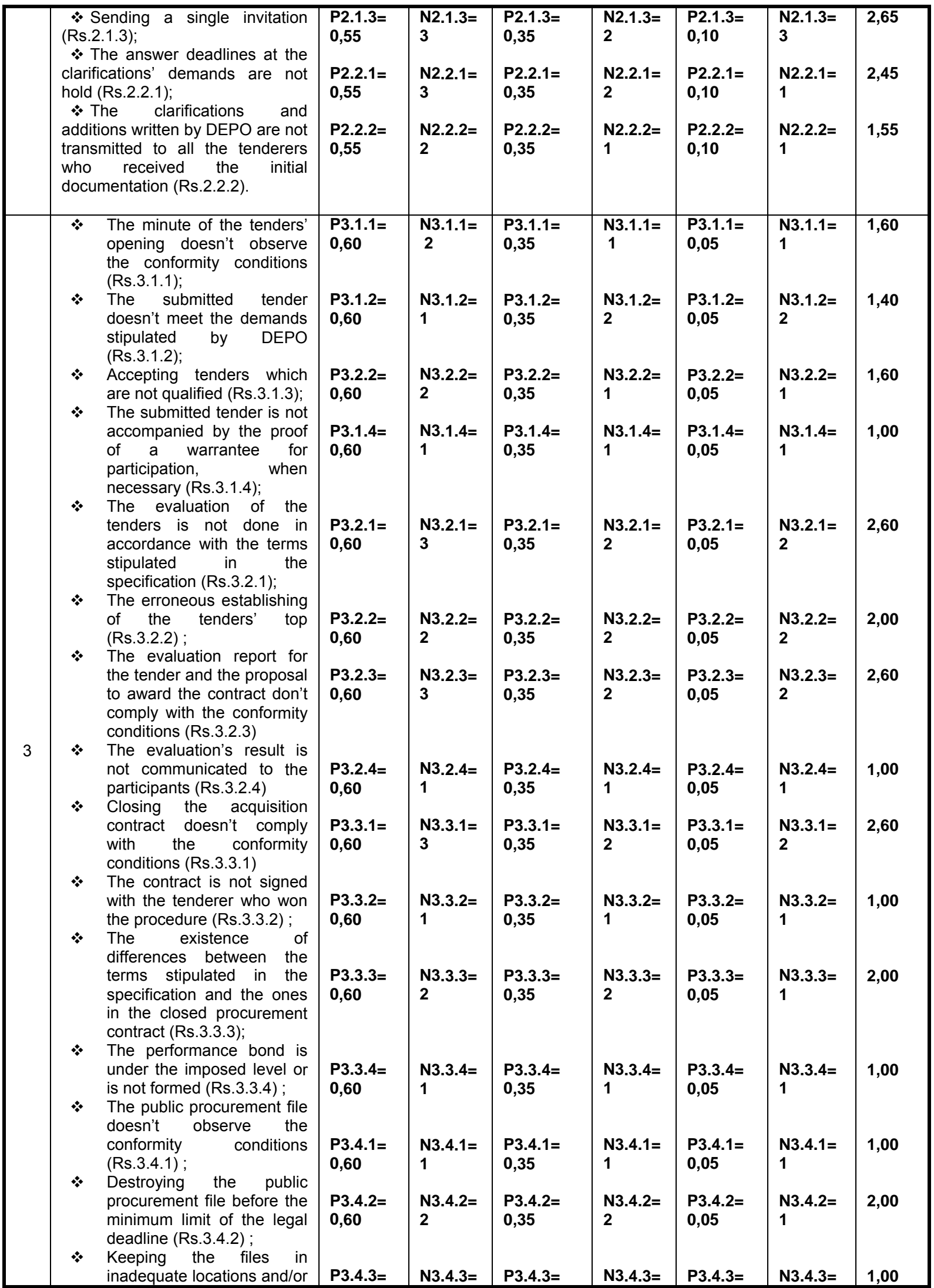


conditions (Rs.3.4.3)

Used terms

The public procurement process

represents the set of activities which are carried out in order to award, close and execute a contract of public procurement, which ensures the definitive or temporary acquirement of products, works or services.

The public procurement contract is a legal act with onerous title, closed in written form, between the contracting authority and the contractor.

The contracting authority is any:

* public authority, as defined by the Constitution, including the legal authorities;

* public institution of local or general interest, autonomous or under the control of a public authority;

* legal person, other than the ones mentioned above, which was founded to run activities of public interest, without a commercial feature;

* legal person of private right who runs activities relevant in one of the
0,35

sectors of public utilities - water, energy,

transport and telecommunications.

The contractor is any person or corporate body, of private right, Romanian or foreign, who was given a public procurement contract, as a supplier, work executor or provider.

The object of the public procurement contract can be:

* one or more products;

* one or more works of construction;

* one or more services.

Product - any physical object or good, included in CPSA, which is not defined as being a service or a work.

Service - any activity whose result is non-material, such as: maintenance, installation, repairs, and even designing.

Work - any construction activities or any combination of them, which leads or not to a result meant to fulfil a technical-economic function.

\begin{tabular}{|c|c|}
\hline \multicolumn{2}{|r|}{ REFERENCES } \\
\hline Cosserat G. W. & $\begin{array}{l}\text { Modern Auditing, 2nd edition, John Wiley \& Sons, Ltd., England, } \\
\text { 2005; }\end{array}$ \\
\hline Genete L. D. & $\begin{array}{l}\text { Evaluarea riscului în auditul financiar contabil. Metode cantitative şi } \\
\text { metode calitative, ANALELE ŞTIINȚIFICE ALE UNIVERSITĂȚII } \\
\text { "ALEXANDRU IOAN CUZA" DIN IAŞI,Tomul LII/LIII Ştiințe Economice } \\
\text { 2005/2006; }\end{array}$ \\
\hline Ghiță M. & Auditul Intern, Editura Economică, Bucureşti, 2004; \\
\hline$* * * * *$ & $\begin{array}{l}\text { Ghid practic pentru realizarea unei misiuni de audit intern pentru } \\
\text { activitatea de achiziții publice, elaborat de U.C.A.A.P.I, în baza Legii } \\
672 / 2002 \text { privind auditul public intern publicată în Monitorul Oficial } \\
\text { nr.953 din } 24.12 .2002 \text { cu modificările ulterioare, respectiv în baza } \\
\text { O.M.F.P. nr. } 38 \text { din } 15.01 .2003 \text { publicat în Monitorul Oficial nr. } 130 \text { din } \\
\text { 27.02.2003 cu modificările ulterioare. }\end{array}$ \\
\hline
\end{tabular}

